\title{
Aplicação da Abordagem Ágil REACT para a Melhoria do Processo de Desenvolvimento de Requisitos: O Caso da W3AS
}

\author{
Luis Fábio Sobral Magalhães ${ }^{1}$, Luiz Márcio Moraes dos Anjos ${ }^{1}$, Gabriel Rego Cavaleiro \\ de Macedo Maia ${ }^{1}$, Luciano de Sousa Pereira ${ }^{1}$, Sandro Ronaldo Bezerra Oliveira ${ }^{2}$, \\ Kleoson Bruno Corrêa dos Santos ${ }^{2}$
}

${ }^{1}$ W3 Automação e Sistemas - Rodovia BR-316, Km 02, s/n, Edf. Next Office, Torre 01 - Sala 807 - Atalaia - Ananindeua - PA - Brasil

${ }^{2}$ Programa de Pós-Graduação em Ciência da Computação - Universidade Federal do Pará (UFPA), Rua Augusto Corrêa, 1 - Guamá - 66075-110 - Belém - PA - Brasil

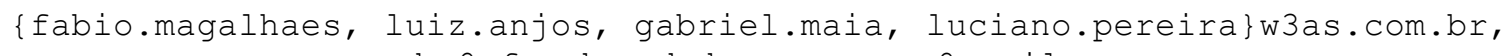

Abstract. The relationship between Requirements Engineering (RE) and agile methods has attracted a lot of attention from researchers in recent years (Daneva et al., 2015), as agile methods have emerged as a great option to minimize some of the problems faced by approaches, such as: low customer involvement, high change in requirements, poorly specified requirements, among others. In this scenario, Santos et al. (2018) proposed a specific agile method to the RE area called REACT (Requirements Evolution in Agile ContexT), a method that was designed from other agile methods. Thus, this presentation aims to describe the report about a case study on the application of REACT, an agile method to support software requirements development, in a real software development environment, the W3AS software factory. This case study assessed the strengths, weaknesses, opportunities, and threats related to the assets that make up REACT, namely: work products, life cycle, roles, and ceremonies. About the results, it was observed that REACT was effective, simple to use, strongly collaborative, suitable, user centered and goal oriented. Thus, achieved its main purpose to evolve the requirements of a software product in iteratively, efficiently and under of the agile mindset.

Resumo. O relacionamento entre a Engenharia de Requisitos (ER) e os métodos ágeis tem atraído bastante atenção dos pesquisadores nos últimos anos (Daneva et al., 2015), em face dos métodos ágeis terem surgido como uma ótima opção para minimizar alguns problemas enfrentados pelas abordagens tradicionais, tais como: pouco envolvimento dos clientes, alta mudança nos requisitos, requisitos mal especificados, dentre outros. Neste cenário, Santos et al. (2018) propuseram um método ágil específico para a área da ER denominado REACT (Requirements Evolution in Agile ContexT), um método que foi concebido a partir de outros métodos ágeis. Assim, esta apresentação ter por objetivo descrever o relato de um estudo de caso sobre a aplicação do REACT, uma abordagem ágil para o desenvolvimento de requisitos de software, em um ambiente real de desenvolvimento de software, a fábrica de software da W3AS. Este estudo de caso avaliou as forças, as fraquezas, as oportunidades e as ameaças relacionadas aos ativos que compóem o REACT, a saber: artefatos, ciclo de vida, papéis e cerimônias. Dentre os resultados, observou-se que o REACT foi efetivo, simples de usar, fortemente colaborativo, suitable, centrado no usuário e orientado a metas. Assim, atendendo ao seu principal objetivo que é evoluir os requisitos de um produto de software de forma iterativa, eficiente e sob o guarda-chuva do mindset ágil.

\section{Referências}

Daneva, M., Inayat, I., Moraes, L., Salim, S. (2015) “A Reflection on Agile Requirements Engineering: Solutions Brought and Challenges Posed”. XP 2015 Workshops, Helsinki, Finland.

Santos, K., Oliveira, S., Filho, J. (2018) "REACT: An Agile Method to Software Requirements Development”. In: 15th International Conference on Information Systems and Technology Management, , São Paulo-SP. 